$\begin{gathered}\text { Ana Dili Eğitimi Dergisi } \\ \text { Journal of Mother Tongue Education } \\ \text { www.anadiliegitimi.com }\end{gathered}$
Geliş/Received: $11.09 .2016 \quad$ Kabul/Accepted:11.10.2016

\title{
Yabancı Dil Olarak Türkçe Öğretiminde İhmal Edilmiş íki Program: 1986 ve 2000 Programları
}

\author{
Ülker ŞEN*
}

\section{Öz}

Öğretim programları, bir dersle ilgili öğrenme yaşantılarına ait düzeneklerdir. Bu düzenek, öğretimin nasıl, hangi stratejilerle ve yöntemlerle ya pılacağına dair bilgiler sunar. Türkçenin ana dili olarak öğretiminde olduğu gibi yabancı dil olarak öğretiminde öğretim programlarının yeri tartışılmazdır. Alan yazındaki birçok çalışma da bu görüşü desteklemektedir. Ancak bununla birlikte alan yazında ki birçok çalışmada herhangi bir kurum tarafından "yabancı dil olarak Türkçe öğretimi" için herhangi bir öğretim programının hazırlanmadığı vurgusu da yapılmaktadır. Oysa Millî Eğitim Bakanlığı ilki 1986 yılında ikincisi 2000 yılında olmak üzere iki kez "Yabancı Dil Olarak Türkçe Öğretimi Programı" yayımlamıştır. Maalesef bu iki program şu ana kadar araştırmacıların dikkatinden kaçmıştır. Bu sebeple çalışma Millî Eğitim Bakanlığının 1986, 2000 yıllarında yayımla dığı "Yabancı Dil Olarak TürkçeÖğretim Programlarına" araştırmacıların dikkati ni çekmek, programlarla ilgili farkındalık oluşturmak amacıyla hazırlanmıştır. Bu amaç için programlar, temele alınan yaklaşım, amaçlar, ölçme değerlendirme, öğrenme süreci ve içerik açısından değerlendirilmiştir. Bu araştırmada betimsel tarama yöntemi kullanılmıştır. Verilerin analizinde betimsel analizden yararlanılmıştır. Yabancı Dil Olarak Türkçe Öğretim Programında (1986) temele alınan yaklaşımın belirtil mediği, 2000 yılında yayımlanan programda iletişimsel yaklaşımın temele alındığı yapılan değerlendirmelerden elde edilen sonuçlardandır.

Anahtar Kelimeler: Yabancı dil olarak Türkçe öğretimi, Öğretim programı, Millî Eğitim Bakanlığı

Neglected Curricula in Teaching Turkish as a Foreign Language: the 1986 and 2000 Curricula

\begin{abstract}
Curricula are layouts which consist of learning experiences in a course. These layouts present information on how, with which strategies, and with which methods teaching will be done. The role of curriculum is indisputable in teaching Turkish as a foreign language as well as its role in teaching it as a native language. Many studies in the literature support this idea as well. However, many studies also suggest that there has not been a curriculum for teaching Turkish as a for eign language prepared by any institution. In fact, the Turkish Ministry of National Education published a curriculum for teaching Turkish as a foreign language two times; the first in 1986 and the second in 2000. Unfortunately, these two curricula have escaped researchers' attention. For this reason, this study was carried out to create a wareness about the aforementioned "Curriculum for Teaching Turkish as a Foreign Language" by the Ministry of National Education in the years 1986 and 2000. These curricula are evaluated in terms of approach, aims, measurement and evaluation, learning process, and content. Descriptive survey model was utilized in this study. One of the main findings of the study is that the approach the "Curriculum for Teaching Turkish as a Foreign Language" (1986) is based on is not mentioned; however, the communicative approach is mentioned as the basis for the curriculum in 2000.
\end{abstract}

Key Words: Teaching Turkish as a Foreign Language, Curriculum, Ministry of National Education

\footnotetext{
* Öğr.Gör. Dr., Gazi Üniversitesi, Gazi Eğitim Fakültesi, Türkçe Eğitimi Ana Bilim Dalı. Ankara. ulker_sen@hotmail.com
} 


\section{Giriş}

Yabancı dil olarak Türkçe öğretiminin tarihi, literatürde 11. yüzyıla kadar uzanırken sistemli bir şekilde yabancı dil olarak Türkçenin öğretimi 20. yüzyılın sonlarına kadar dayandırılır. 1984 yılında Ankara Üniversitesi bünyesinde açıllan Türkçe Öğretim Merkezi (TÖMER) yabancı dil olarak Türkçenin öğretiminin planlı ve sistemli öğretimi için önemli bir basamaktır. Ankara Üniversitesi Türkçe Öğretim Merkezini 1994 yılında Gazi Üniversitesi Türkçe Öğretim Merkezi (TÖMER) takip etmiştir. 1984yılından günümüze kadar giderek Türkçe Öğretim Merkezlerinin sayısı artmıştır. Kurumsal anlamda yabancı dil olarak Türkçe öğretiminde olumlu bir seyir takip edilse de alanın diğer bazı konularında sorunlar, eksiklikler hâlâ devam etmektedir. Alan yazında tespit edilen sorunlar arasında öğretim programı ile ilgili konulardaki sorunlar dikkat çekicidir. Erdem, Gün, Şengül, Özkan (2015), yabancı dil olarak Türkçe öğretimi ile ilgili 160 bilimsel makal edegeçen anahtar sözcüklerden hareketle alanın sorunlarını tespit etmek için hazırladıkları çalışmalarında "Yabancı Dil Olarak Türkçe Öğretimi Programı" teması altında 22 anahtar kelime tespit etmiştir. Erdem ak. (2015), elde ettikleri verilerden hareketle alan yazınının en büyük eksikliğinin yabancı dil olarak Türkçe öğretiminde ortak bir hareket noktası oluşturacak öğretim programının olmaması olarak belirtmiştir. Er, Biçer ve Bozkırlı (2012) da yaptıkları çalışmalarında öğretim programı alanında yetersizlikler olduğunu ifade etmişlerdir. İlgi li çalışmada "öğretim programı yetersizliği" başlığı altında yabancılara Türkçe öğretimi programlarının Avrupa Dil Dosyası göz önünde bulundurularak hazırlanmaması, öğrencinin ihtiyacına cevap verebilecek nitelikte bir programın olmaması, yabancılara Türkçe öğretimine yönelik programların uzman kişilerce hazırlanmamış olması, ortak bir programın olmaması, ders saati yetersizliği gibi alt sorunlan sıralamışlardır. Açık (2008), Göçer ve Moğul (2011), Kara (2011) ise yabancı dil olarak Türkçenin öğretiminde programın gerekliliğini ve programın çerçeve metne (Common European Framework of Reference for Languages: Learning, Teaching, Assessment) uygun şekilde hazırlanması gerektiğini vurgulamışlardır. Alan yazında bu önerilerin ötesinde Erdem vd. (2015), daha iddialı bir şekilde Türkiye'deki herhangi bir kurumun şimdiye kadar yabancı dil olarak Türkçe öğretim programı adı altında herhangi bir program yayımlamadığını ifade etmiştir:

"MEB'in ve başka herhangibir kurumun "Yabancı Dil Olarak Türkçe Öğretimi Programı" adı altında herhangibiröğretim programının olmadığı herkesçe bilinmektedir. Bu eksiklik yabancı dil olarak Türkçe öğreten kurumların ortak hareket etmesini sınırlamış, öğretimde farkllıklar meydana getirmiştir. Belirlenen yıllarda yabancı dil olarak Türkçe öğretiminde Avrupa Diller İçin Ortak Başvuru Metni ışığında bazı çalışmalarda dil düzeylerine yönelik program örnekleri oluşturulmaya çalışılmıştır. Ancak çalışmaların yeterli olduğunu söylemek mümkün değildir( Erdem ve ark.,2015: 232)."

Yukarıda verilen bilgiler ve alan yazın değerlendirildiğinde kimi tespitlerin yerinde olduğu kimi tespitlerin ise eksik olduğu söylenebilir. Örneğin herkesçe kabul edilecek bir "yabacı dil olarak Türkçe öğretimi çerçeve programı”, alanın önemli bir ihtiyacıdır. Ancak Millî Eğitim Bakanlığının ve başka herhangi bir kurumun "Yabancı Dil Olarak Türkçe Öğretimi Programı” adı altında herhangi bir öğretim 
programı hazırlamadığı gerçeği yansıtmamaktadır. 2015 yılında M. Ertan Gökmen editörlügünnde Ankara Üniversitesi TÖMER tarafından "Yabancı Dil Olarak Türkçe Öğretim Programı" hazırlanmıştır. Bu öğretim programında alanın ilki olma özelliğine sahip olduğu ifade edilse de bu programdan daha eski olarak MillîEğitim Bakanlığı ilki 1986 yılında ikincisi 2000 yılında olmak üzere Türkçenin yabancı dil olarak öğretimi ile ilgili iki kez program yayımlamıştır. Yurt Dışı İşçi Çocukları Türkçe-Türk Kültürü ile Yabancı Dil Olarak Türkçe Öğretim Programları, Kitap Yazma Seferberliği Yüksek İcra Kurulu Başkanlığının 15.10.1985 tarih ve 651 sayılı teklifi üzerine Millı̂ Eğitim Gençlik ve Spor Bakanlığı Talim Terbiye Kurulu Başkanlığının 27.1.1986 tarih ve 29 sayılı kararı ile Eğitim ve Öğretim Yüksek Kurulu Başkanlığının 11.2.1986 tarih ve 2 sayılı kararı ile kabul edilmiştir. Program dört bölümden oluşmaktadır. Birinci bölümde, Yurt Dışındaki İşçi Çocukları Iç̧in Türkçe-Türk Kültürü Öğretim Programı yer almaktadır. İkinci bölümde Sosyal Bilgiler, Tarih, Coğrafya, Vatandaşlık Bilgisi, İnkılap Tarihi, Atatürkçülük Programı, üçüncü bölümde Müzik Programı, dördüncü bölümde Yabancı Dil OlarakTürkçe Öğretim Programı yer almıştır. Yurt Dışındaki Türk Çocukları İçin Türkçe (1-10. Sınıflar), Türk Kültürü (4-10. Sınıflar) ve Yabancı Dil Olarak Türkçe (6-11. Sınıflar) Dersleri Öğretim Programları ise Dış iliş̧kiler Genel Müdürlüğünün 20.09.2000 tarih ve 10046 sayılı teklif yazıları üzerine MillîEğitim Bakanlığı Talim Terbiye Kurulu Başkanlığının 23.10.2000 tarih ve 388 sayılı kararı ile kabul edilmiştir. Yurt Dışındaki Türk Çocukları İçin Türkçe (1-10. Sınıflar), Türk Kültürü (4-10. Sınıflar) ve Yabancı Dil Olarak Türkçe (611. Sınıflar) Dersleri Öğretim Programları bir önceki programın yenidengözdengeçirilerek genişletilmiş hâlidir. Program, Türkçe Dersi Öğretim Programı (1-10. sınıflar), Türk Kültürü Dersi Öğretim Programı (4-10. Sınıflar) ve Yabancı Dil Olarak Türkçe Dersi Öğretim Programı (6-11. Sınıflar) bölümlerinden oluşmaktadır.

Görüldüğü üzere yabancı dil olarak Türkçe öğretimi konusunda programlar hazırlanmıştır, ancak bu tespitlerin ötesinde dikkat çekilmesi gereken esas nokta, alan yazında (birkaç bibliyografik çalışma dışında) Millî Eğitim Bakanlığının 1986 ve 2000 yııında yayımlamışolduğu yabancı dil olarak Türkçe öğretim programlarının bilinmemesi ve programlar üzerine çalışmaların yapılmamış olmasıdır. Bu noktadan hareketle çalışmanın temel amacı, Millî Eğitim Bakanlığının 1986, 2000 yıllarında yayımladığı "Yabancı Dil Olarak Türkçe Öğretim Programı” ve "Yurt Dışındaki Türk Çocukları Iç̧in Yabancı Dil Olarak Türkçe Dersi Öğretim Programı (6-11. Sınıflar)"na araştırmacıların dikkatini çekmek, programlarla ilgili farkındalık oluşturmaktır. Bu temel amaç ışığında her iki programı Temele Alınan Yaklaşım, İçerik, Amaçlar, Öğrenme-Öğretme Süreci, Ölçme ve Değerlendirme açısından incelemek çalışmanın alt amacıdır.

\section{Yöntem}

Bu araştırmada "betimsel tarama yöntemi" kullanılmıştır. Tarama yöntemi, hâlihazırda mevcut olan veya geçmişte olmuş bir durumu olduğu şekliyle betimleyen bir çalışma yöntemidir (Karasar, 
2008). Veriler, doküman taraması yoluyla elde edilmiştir. Verilerin analizinde betimsel analizden yararlanılmıştır. Betimsel analizde; elde edilen veriler, daha önceden belirlenen başlıklar altında özetlenirve yorumlanır (Altunışık, Çoşkun, Yıldırım ve Bayraktaroğlu, 2010). Bu çalışmada da betimsel analize uygun olarak öncelikle konu ile ilgili bir çerçeve oluşturulmuştur, çerçeveye uygun başlıklar belirlenmiştir, belirlenen başlıklar altında bulgular sıralanmış, son olarak bulgular yorumlanmıştır.

Çalışma, "Yurt Dışı İşçi Çocukları Türkçe-Türk Kültürü ile Yabancı Dil Olarak Türkçe Öğretim Programları" (MEGSB, 1986) ve "Yurt Dışındaki Türk Çocukları Için Türkçe (1-10. Sınıflar), Türk Kültürü (4-10. Sınıflar) ve Yabancı Dil Olarak Türkçe (6-11. Sınıflar) Dersi Öğretim Programları"nın (MEB, 2000) yabancı dil olarak Türkçe öğretim programlarına ait bölümlerinin değerlendirilmesi ile sınırlıdır. Programlar ile ilgili bilgiler verilirken ilk program için Yabancı Dil Olarak Türkçe Öğretim Programı (MEGSB, 1986), ikinci program için Yabancı Dil Olarak Türkçe Dersi Öğretim Programı (MEB, 2000) ifadeleri kullanılmıştır.

\section{Bulgular}

Bu çalışma nitel bir çalışma olarak hazırlanmıştır. Tespit edilen bulgular betimsel analiz tekniğine uygun olarak sunulmuştur.

\section{Temele Alınan Yaklaşım Açısından}

Yabancı Dil Olarak Türkçe Öğretim Programında (MEGSB, 1986) temele alınan yaklaşım konusunda doğrudan bir bilgi verilmemiştir. Yabancı Dil Olarak Türkçe Dersi Öğretim Programında (MEB, 2000: 1) iletişimsel yaklaşımın temele alındığı görülmektedir. Açıklamalar başlığı altında şu ifadelere yer verilmiştir: "Küreselleşen dünyada, ülkeler arasında iletişim ön plana geçmiştir. Bu bağlamda, yabancı dil öğretiminde de iletişimsel yaklaşım esas kabul edilmiştir. Öğrenci merkezli öğretimi esas alan bu yaklaşımda dil kurallarının kullanımı büyük önem taşır. Öğrencinin ilgi ve ihtiyaçları, başka bir deyişle, kullanacağı sözcük, deyim ve yapılar büyük önem taşır. Yabancı dil öğretiminde, doğrudan dil bilgisi kurallarını konu olarak öğretmek yerine, iletişimi esas alan ve dil bilgisi kurallarını da metinler içinde islemeyi amaçlayan bir yöntem izlenir."

içerik

Yabancı Dil Olarak Türkçe Öğretim Programı (1986)nda öğrenme alanları ve ya dil becerileri belirtilmemiştir. Program Genel Amaçlar, Özel Amaçlar, Açıklamalar, Yabancı Dil Olarak Türkçe Öğretimi Konuları ana başlıklarından oluşmaktadır. Genel amaçlar 10 madde ile ifade edilmiştir. Özel amaçlar 1. Başlangıç Devresi (5.- 6. sınıflar ), 2. Orta Devre (7.- 8.sınıflar), 3. İleri Devre (9.-10. sınıflar) alt başlıklarına ayrılarak her devre için ayrı ayrı amaçlar ifade edilmiştir. Açıklamalar başlığı altında ise A. Yabancı Dil Olarak Türkçe Öğretiminin Genel İlkeleri, B. Öğretim Metodu İle Illgili Genel Bilgiler, C. Öğretim Araçları, D. Ödevler alt başı ıklarında çeşitli açıklamalar yapıımıştır. Yabancı dil olarak Türkçe 
öğretimi konuları sınıf veya öğrenme alanlarına göre verilmemiştir. Bunun yerine kitaplar üzerinden öğretilecek konular verilmiştir. Yabancı dil olarak Türkçe öğretimi konuları altı kitaba göre tasnif edilmiştir. Her bir kitap için Fonksiyonlar-ifadeler ve Dilbilgisi konuları sıralanmıştır. Bu kitapların konuları seviyelere göre belirlenmiştir. Bir ve ikinci kitap başlangıç, üç ve dördüncü kitap orta, beş ve altıncı kitap ileri devre içindir.

Yabancı Dil Olarak Türkçe Dersi Öğretim Programı (MEB, 2000), Anlama ve Anlatma temel dil becerileri üzerine inşa edilmiştir. Anlama beceriler Dinlediğini Anlama Becerisi, Okuduğunu Anlama Becerisi; Anlatma becerileri ise Konuşma Becerisi, Yazma Becerisini oluşturmaktadır. Programda her bir beceri için amaç ve davranışlar belirlenmiştir. Programın içeriği sırasıyla şu şekilde ol uşturulmuştur: İkinci Yabancı Dil Olarak Türkçe Dersi İçin Protokol, Türk Millî Eğitiminin Amaçları (3 madde), Giriş, Açıklamalar (20 madde), Türkçe Öğretiminde Kullanılan Temel Dil Becerileri I. Anlama: a. Dinlediğini Anlama Becerisi b. Okuduğunu Anlama Becerisi II. Anlatım: a. Konuşma Becerisi, b. Yazma Becerisi, Ölçme ve Değerlendirme İle İlgili Bilgiler (Anlama ve Yazma Becerilerinin Ölçülmesiyle İlgili Bilgiler, Anlatımla İlgili Ölçme Bilgisi), Seçilecek Metinlerle İlgili Temel illkeler (14 madde), Genel Amaçlar, Amaçlar ve Davranışlar: 6. Sınıf, 7.Sınıf, 8.Sınıf (Ders İşleniş Örneği), 9. Sınıf, 10. Sınıf, 11. Sınıf. Programda 6-7. sınıflar Temel Düzey, 8-9. sınıflar Orta Düzey, 10-11. sınıflar ileri düzeyi temsil etmektedir.

\section{Amaçlar}

Yabancı Dil Olarak Türkçe Öğretim Programı (MEGSB, 1986: 1), "yurt dışında doğmuş, anne veya babası yabancı olduğu için Türkçeyi öğrenememişyurt dışında yaşayan Türk çocukları ile Türkçeyi yabancı dil olarak öğrenecek yabancı çocuklara Türkçe öğretmek" amacıyla hazırlanmıştır. Programla ifade edilen hedef kitlenin Türkçe konuşabilmesi, yazabilmesi, okuyabilmesi, Türkçe konuşulanları anlayabilmesi, Türk çocuklarının Türkiye ile olan bağlarının devam etmesi, Türkçe öğretimi sırasında Atatürk inkılâp ve ilkeleri ile Türklük şuurunu pekiştirme ve geliştirme, Türk örf ve âdetlerini benimsetme; yabancıların Türklerle anlaşabilmelerini sağlama gibi amaçlar programın genel amaçlan arasındadır. Programda belirtilen bu genel amaçlar Tablo 1'de gösterilmiştir.

Tablo 1: Yabancı Dil Olarak Türkçe Öğretim Programı (MEGSB, 1986) genel amaçlar

\begin{tabular}{l}
\hline Genel Amaçlar \\
\hline 1. Türkçe konuşmaları anlayabilmek \\
2. Anlaşılır bir şekilde Türkçe konuşabilmek \\
3. Türkçe yazıları okuyabilmek \\
4. Türkçe bir parçayı sesli ve sessiz okuduğunda doğru olarak anlayabilmek \\
5. Duygu ve düşüncelerini yazı ve sözle Türkçe anlatabilmek \\
6. Türkçe öğretimi sırasında Atatürk inkılap ve ilkeleri ile Türklük şuurunu \\
pekiştirme ve geliştirme, Türk örf ve adetlerini benimsetmek (Türk çocukları \\
için)
\end{tabular}


7. Türkçe ve Türk kültürünün yurt dışında tanıtılması, yayılması ve çocuklarımızın Türkiye ile bağlarının korunması ve güçlendirilmesine yardımcı olmak

8. Okuldan sonra da Türkçeyi ana dili olarak geliştirip, kullanabilmek (Türk çocukları için)

9. Türkçenin Türklerle yabancılar arasında anlaşma aracı olarak kullanılmasına ortam hazırlamak (yabancılar için)

10. Türkiye'ye turistik, ticari öğrenim vb. amaçlarla gelecek olan yabancıların Türklerle anlaşabilmelerine yardımcı olmak

Yabancı Dil Olarak Türkçe Öğretim Programında (MEGSB, 1986) başlangıç, orta ve ileri devre olarak belirlenen seviyelere göre özel amaçlar belirlenmiştir. Amaçlar dil beceri düzeylerine göre sınıflandırılmamıştır. Seviyelerde birbirini tekrarlayan amaçlar olduğu gibi birbirinin devamı veya tamamlayıcısı olan amaçlar da bulunmaktadır.

Tablo 2-1: Yabancı Dil Olarak Türkçe Öğretim Programı (MEGSB, 1986) özel amaçlar

\begin{tabular}{|c|c|}
\hline Sınıflar & Özel Amaçlar \\
\hline $\begin{array}{l}\text { 1. Başlangıç devresi } \\
\text { (5.- 6. sınıflar) }\end{array}$ & $\begin{array}{l}\text { a. Basit cümlelerin bulunduğu bir parça da geçen kelimelerin anlam } \\
\text { bilgisini kazandırmak. } \\
\text { b. Basit cümleleri anlayabilmek. } \\
\text { c. Dilimizin ana kurallarını sezdirme yoluyla kavratmak. } \\
\text { ç. Basitcümlelerden oluşan bir parçayı dinlediğindeanlayabilmek. } \\
\text { d. Basitcümlelerden oluşan bir parçayı başka bir anlatımbiçimine } \\
\text { çevirebilmek. } \\
\text { e. Normal hızda, seviyesine uygun karşılıklı bir konuşmayı } \\
\text { anlayabilmek. } \\
\text { f. Seviyesine uygun bir parçayı okuduğunda anlayabilmek. } \\
\text { g. Basit cümlelerle normal hızda ve düzgün bir telaffuzla } \\
\text { konuşabilmek. } \\
\text { ğ. Bir metinde veya konuşmada geçen bilmediği kelimelerin } \\
\text { anlamlarını kestirebilmek. } \\
\text { h. Günlük hayatını basit cümlelerle yazılı olarak ifade edebilmek. } \\
\text { ı. Türkçe öğrenmeye hevesli olmak. } \\
\text { i. Türkçe öğrenmekten zevk almak. }\end{array}$ \\
\hline $\begin{array}{l}\text { 2. Orta devre } \\
\text { (7.- 8.sınıflar) }\end{array}$ & $\begin{array}{l}\text { a. Genellikle birleşik cümlelerden oluşan bir parçada geçen } \\
\text { kelimelerin anlam bilgisini vermek. } \\
\text { b. Bileşik cümle ögelerinin sıra bilgisini öğretmek. } \\
\text { c. Türkçe imla kuralları bilgisini benimsetmek. } \\
\text { ç. Seviyesine uygun bir parçayı dinlediğinde, anlayabilme } \\
\text { melekesini geliştirmek. } \\
\text { d. Seviyesine uygun bir parçayı okuduğunda kavrayabilmek. } \\
\text { e. Basit ve bileşik cümleleri kullanaraknormal hızda ve düzgün bir } \\
\text { telaffuzla konuşabilmek. } \\
\text { f. Günlük hayatla ilgili bir konuşmada geçen kelime ve deyimlerin } \\
\text { anlamını cümlenin gelişinden kestirebilmek. } \\
\text { g. Günlük hayatı tabi bir biçimde sözlü olarak anlatabilmek. } \\
\text { ğ. Günlük hayatı bileşik cümlelerde kullanarak, yazılı olarak ifade } \\
\text { edebilmek. } \\
\text { h. Seviyesine uygun Türkçe yayınları izlemeye istek duymak ve } \\
\text { izleyebilmek. } \\
\text { ı. Türkçe konuşmaktan zevk alabilmek. }\end{array}$ \\
\hline
\end{tabular}


Tablo 2-2: Yabancı Dil Olarak Türkçe Öğretim Programı (MEGSB, 1986) özel amaçlar

\begin{tabular}{|c|c|}
\hline $\begin{array}{l}\text { 3. Illeri Devre } \\
\text { (9.-10. sınıflar) }\end{array}$ & $\begin{array}{l}\text { a. Seviyelerine uygun roman, hikâye vb. sanat yazılarında geçen } \\
\text { kelimelerin anlam bilgisini öğretebilmek. } \\
\text { b. Roman, hikâye, tiyatro vb. eserlerle ilgili tür ve şekil bilgilerini } \\
\text { vermek. } \\
\text { c. Seviyelerine uygun bir metinde bilinenler yardımıyla bilinmeyen } \\
\text { kelime ve deyimlerin anlamını kavrayabilme yeteneğini } \\
\text { kazandırmak. } \\
\text { ç. Duygu ve düşünceleri çeşitli şekillerde (hikâye etme, tasvir etme, } \\
\text { tanımlama, açıklama, tartışma, vb. ) sözle ve yazıyla ifade } \\
\text { edebilmek. } \\
\text { d. Türkçe kompozisyon yazmada dikkat edilecek kuralları } \\
\text { benimsetmek. } \\
\text { e. Seviyesine uygun bir edebîmetni inceleyip, eleştirebilmek. } \\
\text { f. Belli başlı Türkyazar veşairlerini tanımaya ve eserlerini okumaya } \\
\text { özendirmek. }\end{array}$ \\
\hline
\end{tabular}

Yabancı Dil Olarak Türkçe Dersi Öğretim Programı (MEB, 2000: 1), "öncelikle yurt dışında yaşayan Türk çocuklarına, daha sonra anne veya babası yabancı olan öğrencilere ve Türkçeyi ikinci yabancı dil olarak seçmek isteyen diğer öğrencilere Türkçeyi öğretmek amacıyla" hazırlanmıştır. Programda bir önceki programda olduğu gibi amaçlarda yabancı vurgusu yapılmamıştır. Programda belirtilen genel amaçlar Tablo 3 'te verilmiştir.

Tablo 3: Yabancı Dil Olarak Türkçe Dersi Öğretim Programı (MEB, 2000) genel amaçlar

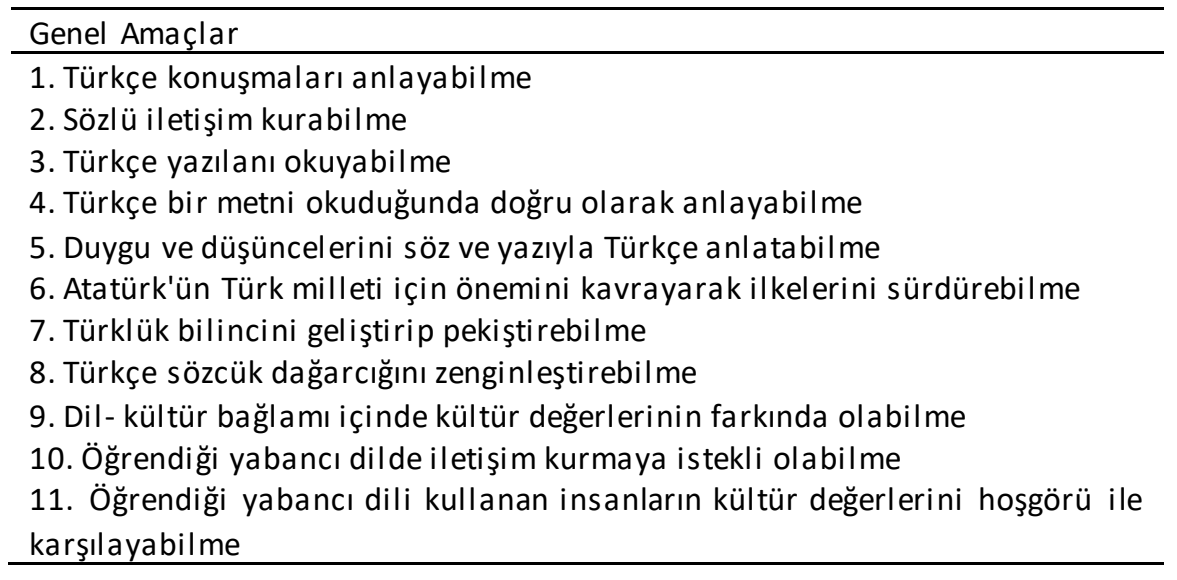

Yabancı Dil Olarak Türkçe Dersi Öğretim Programında (MEB, 2000) bir önceki programdan farklı olarak her sınıf seviyesi için ayrı ayrı özel amaçlar belirlenmiştir. Bu özel amaçlar temel dil becerilerine göre bir sınıflandırmaya tabi tutulmamıştır.

Tablo 4: Yabancı Dil Olarak Türkçe Dersi Öğretim Programı (MEB, 2000) özel amaçlar (6. sınıf)

6. Sınıf Amaçlar
1. Dinlediği bir konuşma ve okuduğu bir metni anlayabilme
2. Sözlükten yararlanabilme
3. Günlük yasamda gerekli olan iletişimi kurabilme
4. Kurallarına uygun bicimde konuşabilme
5. Sayı kavramını kazanabilme
6. Zaman kavramını kazanabilme
7. Atatürk'ü ve yaptığı hizmetleri tanıyabilme
8. Temel dil yapılarını uygulayabilme
9. Türkçe öğrenmeye istekli oluş


Programda 6. sınıf öğrencileri için 9 amaç belirlenmiş olup başlangıç seviyesidir. Bu seviyede programın amaçlarına göre bireyden temel dil yapılarını uygulayabilmesi, temel düzeyde Türkçe konuşma, okuma ve dinleme becerisinin kazanılması beklenmektedir.

Tablo 5: Yabancı Dil Olarak Türkçe Dersi Öğretim Programı (MEB, 2000) özel amaçlar (7. sınıf)

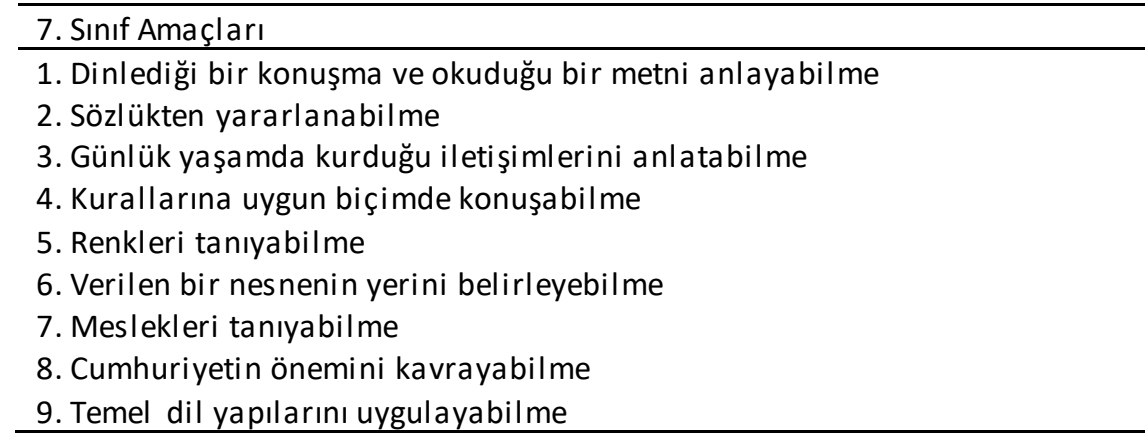

7. sınıfın amaçlarında da bireyin dinleme, konuşma ve okuma becerileri üzerinde durulduğu görülmektedir. Bir önceki sınıfta "Atatürk'ü ve yaptığı hizmetleri tanıyabilme" amacı 7. sınıfta yerini "Cumhuriyetin önemini kavrayabilme" amacına bırakmıştır.

Tablo 6: Yabancı Dil Olarak Türkçe Dersi Öğretim Programı (MEB, 2000) özel amaçlar (8. sınıf)

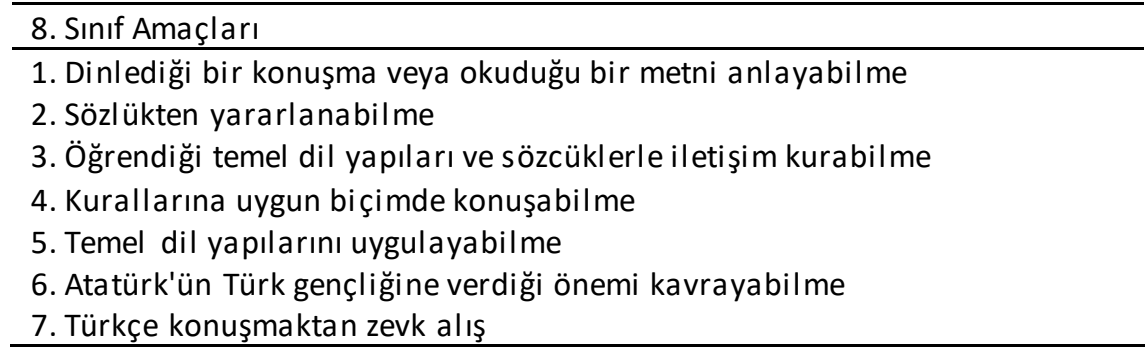

Diğer kademeler de göz önüne alındığında 8. sınıf, en az özel amaca sahip devreyi temsil etmektedir. Aynı zamanda 8. sınıf, orta düzey Türkçe dil becerilerinin kazandırılmasının amaçlandı̆̆ı seviyedir. Bu devre, dinleme, konuşma, sözlük bilgisi, iletişim, temel dil yapıları, Atatürk'ün Türk gençliğine verdiği önem, Türkçe konuşmaktan zevk alıs ifadeleri üzerinde şekillenmiştir.

Tablo 7: Yabancı Dil Olarak Türkçe Dersi Öğretim Programı (MEB, 2000) özel amaçlar (9. sınıf)

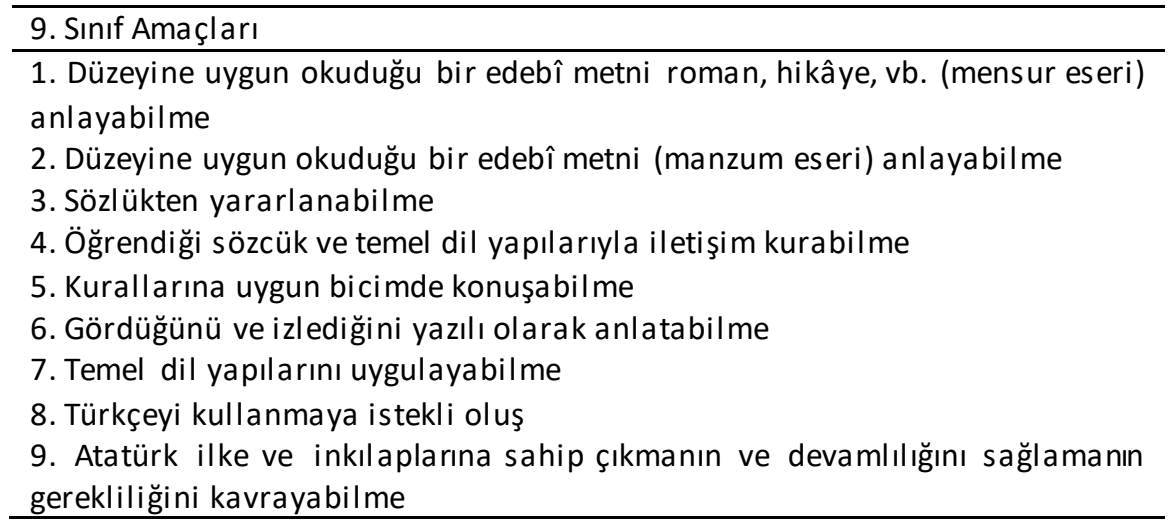

9. sınıf, 8. sınıfla birlikte orta düzey dil becerilerinin kazandıııldığı sınıftır. Bu dönemde edebî metin kavramı devreye girmektedir. Yazma becerisi amaçlarda ilk kez bu sınıfta kendisine yer bulabilmiştir. Dinleme becerisine ilişkin amaç ifadesi bulunmamaktadır. 
Tablo 8: Yabancı Dil Olarak Türkçe Dersi Öğretim Programı (MEB, 2000) özel amaçlar (10. sınıf)

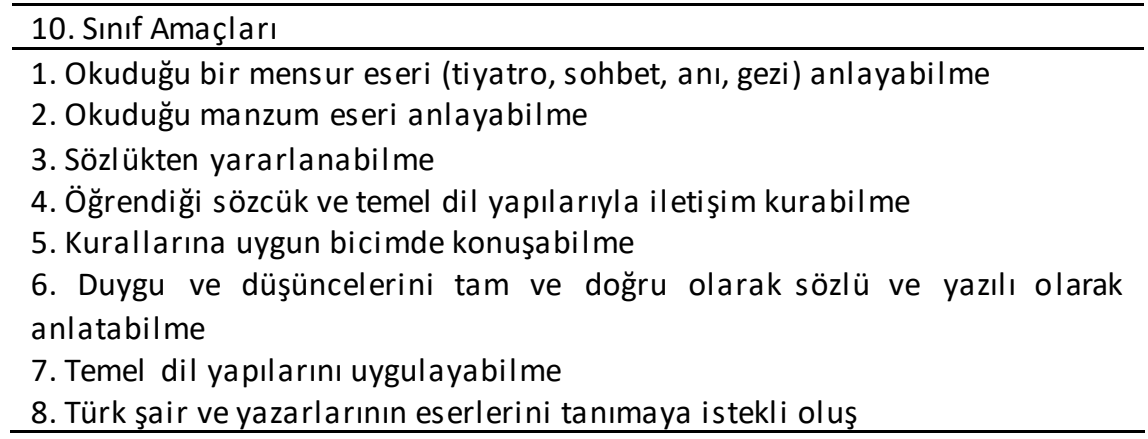

Tablo 8'de 10. sınıflarda Türkçe öğretimin amaçları verilmektedir. Buna göre bir önceki sınıfta edebî metin kavramı yerini mensur ve manzum eser kavramlarına bırakmıştır. Önceki dört sınıfın aksine Atatürkçülük konusuna ilişkin amaç ifadesi bu sınıfta yer almamaktadır.

Tablo 9: Yabancı Dil Olarak Türkçe Dersi Öğretim Programı (MEB, 2000 ) özel amaçlar (11. sınıf)

11. Sınıf Amaçları
1. Verilen bir düşünce yazısını (deneme, eleştiri, makale, fıkra) anlayabilme
2. Verilen bir manzum eseri anlayabilme
3. Görüp izlediklerini sözlü olarak anlatabilme
4. Çevresindeki ünlü kişiler ile ünlü Türk büyüklerini tanıyabilme
5. Düzeyine uygun röportaj yapabilme
6. Verilen bir metin veya diyalogda temel dil yapılarını kullanarak bilinenler
yardımıyla bilinmeyenleri kestirebilme
7. Dinlediği ve izlediği konularda sözlü ve yazılı olarak yorum yapabilme
8. Temel dil yapılarını uygulayabilme
9. Türkçe yayınları okumaktan zevk alış

11. sınıf, 10. sınıfla birlikteileri düzeyTürkçe dil becerilerinin kazandırıldığı sınıftır. Bu dönemde deneme, eleştiri, makale, röportaj gibi edebîtürlerin öğretimiön plandadır. Daha önce de kısmenifade edildiği gibi Yabancı Dil Olarak Türkçe (6-11. Sınıflar) Dersi Öğretim Programında (MEB, 2000) 6-7. sınıflar temel seviye, 8 - 9. sınıflar orta seviye, 10-11. sınıflar ise ileri seviye olarak kabul edilmektedir. Programda yukarıda verilen amaçlardan ayrı olarak iletişimsel yaklaşım temelinde her bir sınıf için konular, konularla ilgili dilin işlevleri ve dilin yapıları ayrı ayrı tablolar hâlinde verilmiştir.

\section{Öğrenme-Öğretme Süreci}

Yabancı Dil Olarak Türkçe Öğretim Programı (MEGSB, 1986), dil öğretim sürecinde dört temel dil becerisinin birlikte geliştirilmesini esasalmıştır (Normal hızla konuşulduğunda anlayabilme, Anlaşılır bir şekilde konuşabilme, Kolaylıkla okuma ve okuduğunu anlama, Düşündüklerini yazıyla ifade edebilme yeteneğini kazandırma). Programda ayrıca dil öğretim sürecinde kolaydan zora, somuttan soyuta, bilinenden bilinmeyene bir sürecin takip edilmesi gerektiği vurgulanmıştır. Öğrenme öğretme sürecine ilişkin dikkat çeken diğer noktalar şunlardır: Yaş ve sınıfa göre değil bilgi seviyesine/durumuna göre seviyelendirme yapılması, temel seviyede konuşma dinleme ağılıklı etkinlikleri yapılması, metinlerin ve örneklerin günlük hayatta yakın / günlük hayatın içinden olması, dilbilgisi kurallarının doğrudan kuralı vermek yerine metinler aracılığı ile sezdirilmesi, sınıf içi dil öğretim çalışmalarında 
laboratuvar, dergi, broşür, bilimsel kitaplar, radyo televizyon, video vb. göze ve kulağa hitabeden araçlara yer verilmesi, sınıf içi çalışmaların öğrencinin kapasitesine ve seviyesine göre düzenlenmesi, dil becerilerinin kalıcılığını sağlamak için çağrışımlar ve tekrarlardan sıklıkla yararlanılması.

Yabancı Dil Olarak Türkçe Öğretim Programına (MEGSB, 1986) göre bütün öğretim kademelerinde; a. Sunma, b. Uygulama, c. Üretme-yaratma olmak üzere üç safhaya yer verilecektir. Programda öğretim için kullanılacak araçlar da şu şekilde sıralanmıştır (MEGSB, 1986: 6):

\section{1. Ögrretmen kılavuzu}

2. Ögrenci Kitabı

3. Alıştırma Kitabı

4. Konuşma için tek resimler ve figürler

5. Ufak tablolar, duvar resimleri

6. Film şeritleri, dialar, filmler

7. Video, ses bantları, plaklar.

Derslerde sadece Türkçenin kullanılması, uygulama çalışmalarına ağılık verilmesi, her derste tek yapıyı sunma ve bilinmeyen kelimelerin bilinen yapılarla, bilinmeyenyapılarınsa; bilinen kelimelerle verilmesi, hataların yerleşmeden hemen düzeltilmesi Yabancı Dil Olarak Türkçe Öğretim Programında (MEGSB, 1986) öğrenme-öğretme sürecine ilişkin önemli detaylardır.

Yabancı Dil Olarak Türkçe (6-11. Sınıflar) Dersi Öğretim Programında (MEB, 2000) öğrenmeöğretme süreci öğrenci merkezlidir ve dilin kurallarının kullanımının sağlanmasına dayalıdır. Öğrenme öğretme sürecine ilişkin dikkat çeken diğer noktalar şunlardır: Sözcük öğretiminin üzerinde durulması, sözlük kullanımına özen gösterilmesi, sözcüklerin sözlük anlamlarının yanında güncel yaşamdaki kullanımlarıyla öğretilmesi, grup çalışmasına ağırlık verilmesi, temel düzeyde başlangıç aşamasının ilk ayında bütün dil öğretiminin öncelikle sözlü olarak yapılması, konuşma dinleme çalışmalanyla Türkçenin seslerinin, yapısının ve vurgusunun sezdirilmesi, görsel ve işitsel araçgereçlerin kullanımına önem verilmesi, derslerin sadece Türkçe kullanılarak işlenmesi, örnekleringünlük yaşamdan seçilmesi, U oturma düzeninde sınıfın düzenlemesi, birden çok bilginin/yapının bir anda öğretilmesinden kaçınılması, bilinen sözcüklerin bilinen yapılarla, bilinmeyen yapıların ise bilinen sözcüklerle öğretilmesi, derste resimli malzeme, fotoğraf, dia, film-şerit ve filmlerin kullanılmasına özen gösterilmesi, sınıf ortamının doğal bir yapıya sahip olması, dile ilişkin hatalar hemen ve sezdirilerek düzeltilmesi, dört temel dil becerisinin birlikte öğretiminin gerçekleştirilmesi.

Programda sözcük öğretiminin şekli aşağıdaki gibi sıralanmıştır (MEB, 2000: 2):

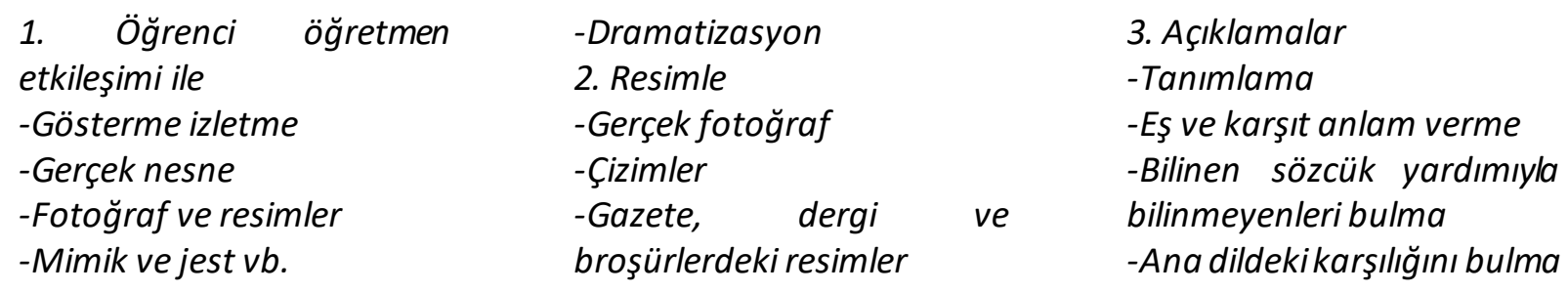


Yabancı Dil Olarak Türkçe Öğretiminde İhmal Edilmiş íki Program: 1986 ve 2000 Programları

Dinleme becerisinin öğretiminde dinleme öncesi, sırasıve sonrasında birtakım uygulamalar ön görülmüştür. Bu uygulamalar dinleme öncesinde dikkat çekme (metin ya da diyalogla ilgili fotoğraf, harita, grafik, resim vs.) çalışmalarının yapılması; dinleme sırasında anlamı bilinmeyen sözcüklerinin anlamlarının tahmin edilmesi, dinleme etkinliğinin duruma göre tekrar ettirilmesi; dinleme sonrasında dinleme metninin özetlenmesive metneyönelik anlama sorularının cevaplanması şeklindedir. Dinleme becerisinin öğretiminde olduğu gibi okuma öncesi, sırası ve sonrasında birtakım uygulamalar ön görülmüştür. Okuma öncesinde metni açıklayan resim varsa resimden, yoksa metnin başlığından hareket edilerek metnin genel olarak anlaşıl ması için bazı ipuçları verilir, okunacak metinle ilgili olarak genel sorular sorulur. Okuma sırasında bilinmeyen bazı sözcüklerin anlamları tahmin edilir, genel bir anlam sağlayacak sözcük ve cümlelerin altları çizilir. Okuma sonrasında metinde geçen anahtar sözcükler bulunur, metinde geçen kişi, yer, zaman bilgilerinin bulunması sağlanır, metni anlamaya yönelik etkinlikler yapıı (boşluk doldurma, yarım cümleyi tamamlama, doğru yanlış soruları gibi). Okuma sonrasında metin özetlenir.

Konuşma becerisi genel olarak sorulan sorulara verilen yanıtlar, sözlü olarak yapılan tekrarlar, diyalog ya da metinle ilgili rol oyunları ile geliştirilir. Yazma becerisinin geliştirilmesinde ise güdümlü yazma, yarı güdümlü yazma ve serbest yazma çalışmalarından yararlanıır. Öğrencilerin yazılı anlatımlarında tespit edilen hataların kâğıt üzerinde gösterilmesi ve öğrencilerin hatalarını farkına varması sağlanır.

\section{Ölçme ve Değerlendirme}

Yabancı Dil Olarak Türkçe Öğretim Programında (MEGSB, 198) ölçme değerlendirmeye ilişkin ayrı bir başlık bulunmamaktadır. Ancak programın belli yerlerinde ölçme ve değerlendirmenin nasıl olması gerektiğine dair birtakım bilgiler mevcuttur. Programda ölçme çalışmalarının sadece öğretilenlere yönelik olması gerektiği öğretilmeyenden öğrencinin sorumlu tutulmaması gerektiği vurgulanmıştır. Programda doğrudan ölçme değerlendirme kapsamında olmasa da ö dev vermenin önemi de vurgulanmıştır. Ödevlerin öğrencilere öğrendiklerini uygulama ve pekiştirme, öğretmene bağlı kalmaksızın ilerleme fırsatı vereceği ifade edilmiştir. Ödevlerin nitelikleri programda şu şekilde ifade edilmiştir (MEGSB, 198: 6):

1. Amaca yönelik, kısa ve öğrenilenleri pekiştirici nitelikte olmalı,

2. Okuma-yazma, yeni kalıplarla cümle kurmaya dönük alıştırmaları kapsamalı,

3. ileri seviyede araştırmaya dayalı olmalı,

4. Uygun örnek veya örneklerle açıklanmalı,

5. Düzenli aralıklarla verilmeli,

6. Kontrol edilip düzeltilmelidir.

Yabancı Dil Olarak Türkçe (6-11. Sınıflar) Dersi Öğretim Programında (MEB, 2000) "Ölçme ve Değerlendirme ille ilgili Bilgiler" başlı̆̆ yer almaktadır. Buna göre ölçme ve değerlendirme 
çalışmalarında ünite düzeyinde birden fazla becerinin teksınavla ölçülmesi sağlanarak, ilgili düzenleme yapılır. Bir yazılı sınavda öğrencinin dille ilgili üç becerisi ölçülmeye çalışılır: Dinlediğini anlama, Okuduğunu anlama, Yazma.

İdeal olan ölçme değerlendirme, her ünite sonunda ara sınavın yapılarak sık sık tekrarlanan hataların tespit edilerek düzeltilme yoluna gidilmesi, dönem notu vermek üzere uygunaralıklarla genel bir sınavın yapılmasıdır. Dört temel beceri için programda önerilen ölçme çalışmalarışu şekildedir (MEB, 2000: 8-9):

a. Dinlediğini Anlama

- Çoktan seçmeli sorular,

- Boşluktamamlamalıanlama tabloları,

- Doğru/yanlıs tabloları (metinden yapılan alıntılar yardımıyla seçilen karşıı̆̆ı doğrulama)

b. Okuduğunu Anlama

- Çoktan seçmeli sorular,

- Doğru/yanlış tabloları,

- Tablo üzerinde tamamlama çalışmaları,

- Kişileri veya ortamı tanımlamaya yarayan, metinden alınmış cümleler,

- Metnin içeriğini anlam bütünlügü içinde yeniden oluşturmaya imkân veren cümlelerin sıraya konulması

- Bir özetteki hataların bulunması vb.

c. Yazma
- Sorulan sorulara yazilı cevap verme, cevabı verilen soruları bulma,

- Kişisel bilgi ve adres yazma ( kart yazma, kimlik kartı doldurma gibi)

- Resimle yazıları esleştirme,

- Eksik bırakılmıs cümle veya paragrafları tamamlama,

- Öğeleri karışık verilmiş cümleleri düzgün hale getirme,

- Replikleri karışık verilmiş bir diyalogu düzgün hale getirme,

- Bir diyalogda boş bırakılmıs replikleri doldurma vb.

d. Sözlü Anlatım

konuşma

- Verilen konu ile ilgili hazırliksı

-Özet yapma

\section{Sonuç}

Sonuç olarak, alan yazındaki, yabancı dil olarak Türkçe öğretim programının olmadığı görüşünün aksine, yabancı dil olarak Türkçe öğretim programlarının olduğu tespit edilmiştir. İlki 1986'da Millî Eğitim Bakanlığı tarafından yayımlanan Yabancı Dil Olarak Türkçe Öğretim Programını yine aynı kurumun 2000 yılında yayımladığı Yabancı Dil Olarak Türkçe Dersi Öğretim Programı takip etmiştir (2015 yılında Ankara Üniversitesi tarafından yayımlanan program, çalışma kapsamında olmadığı için bu programa ait değerlendirme yapılmamıştır). Çalışma kapsamında değerlendirilen iki programın hedef kitlesi Türkçeyi öğrenememiş yurt dışında yaşayan Türk çocukları ile Türkçeyi yabana dil olarak öğrenecek yabancı çocuklardır.

Yabancı Dil Olarak Türkçe Öğretim Programına (MEGSB, 1986) ilişkin elde edilen sonuçlar şu şekildedir: Programda temele alınan yaklaşımın ne olduğuna ilişkin doğrudan bir ifade yer almamaktadır. Programda genel amaçlar ve özel amaçlar belirtilmiştir. Genel amaçlar 10 madde halinde sıralanmıştır. Özel amaçlarise 1. Başlangıç Devresi (5.- 6. sınıflar) 12 madde, 2. Orta Devre (7.8.sınıflar) 11 madde, 3. Ileri Devre (9.-10. sınıflar) 7 madde ile belirtilmiştir. Bütün öğretim 
kademelerinde dil öğretim etkinliklerinin; a. Sunma, b. Uygulama, c. Üretme-yaratma ol mak üzere üç safhada yapılması gerektiği ifade edilmiştir. Ayrıca dört temel dil becerisinin birlikte geliştirilmesi ve dile ait kuralların ezberletilmesi, doğrudan söylenmesi değil sezdirilmesi yoluna gidilmesi gerektiği vurgulanmıştır. Programın içeriği şu şekilde sıralanmıştır: Genel Amaçlar; Özel Amaçlar, 1. Başlangıç Devresi (5.- 6. sınıflar), 2. Orta Devre (7.- 8.sınıflar), 3. Illeri Devre (9.-10. sınıflar); Açıklamalar, A. Yabancı Dil Olarak Türkçe Öğretiminin Genel illkeleri, B. Öğretim Metodu İle illgili Genel Bilgiler, C. Öğretim Araçları, D. Ödevler; Yabancı Dil Olarak Türkçe Öğretimi Konuları; 1. Kitap FonksiyonlarIfadeler Dilbilgisi; 2. Kitap Fonksiyonlar-Ifadeler Dilbilgisi; 3. Kitap Fonksiyonlar-Ifadeler Dilbilgisi; 4. Kitap Fonksiyonlar-ifadeler Dilbilgisi; 5. Kitap Fonksiyonlar-Ifadeler Dilbilgisi; 6. Kitap Fonksiyonlar Dilbilgisi. Programda ölçme ve değerlendirme başlığı bulunmamaktadır. Ölçme adına ölçme çalışmalarının sadece öğretilenlere yönelik olması gerektiği öğretilmeyenden öğrencinin sorumlu tutulmaması gerektiği yönündeki ifade dışında süreçte ölçme ve değerlendirmenin nasıl yapılacağına ilişkin bilgi bulunmamaktadır.

Yabancı Dil Olarak Türkçe Dersi Öğretim Programına (MEB, 2000) ilişkin elde edilen sonuçlar şu şekildedir: Programda temele alınan yaklaşım iletişimsel yaklaşımdır. Programda genel amaçlarve özel amaçlar belirtilmiştir. Genel amaçlar 11 madde halinde sıralanmıştır. Özel amaçlar 6. sınıftan 11. sınıfa kadar ayrı ayrı verilmiştir. 6. sınıfta 9 amaç, 7. sınıfta 9 amaç, 8. sınıfta 7 amaç, 9. sınıfta 9 amaç, 10. sınıfta 8 amaç, 11. sınıfta 9 amaç belirtilmiştir. Öğrenme-öğretme süreci öğrenci merkezlidir ve dilin kurallarının kullanımının sağlanmasına dayalıdır. Dil öğretim sürecinde sözcük öğretimi önemli bir yerdedir. Programda sözcük öğretimi 1. Öğrenci öğretmen etkileşimiyle, 2. Resimle, 3. Açıklamalarla yapılmaktadır. Programın içeriği şu şekildedir: Ikinci Yabancı Dil Olarak Türkçe Dersi İçin Protokol, Türk Millî Eğitiminin Amaçları (3 madde), Giriş, Açıklamalar (20 madde), Türkçe Öğretiminde Kullanılan Temel Dil Becerileri I. Anlama: a. Dinlediğini Anlama Becerisi b. Okuduğunu Anlama Becerisi II. Anlatım: a. Konuşma Becerisi, b. Yazma Becerisi, Ölçme ve Değerlendirme İle Illgili Bilgiler (Anlama ve Yazma Becerilerinin Ölçülmesiyle İlgili Bilgiler, Anlatımla İlgili Ölçme Bilgisi), Seçilecek Metinlerle İlgili Temel ilkeler (14 madde), Genel Amaçlar, Amaçlar ve Davranışlar: 6. Sınıf, 7.Sınıf, 8.Sınıf (Ders Işleniş Örneği), 9. Sınıf, 10. Sınıf, 11. Sınıf. Programda Ölçme ve Değerlendirme ille il gili Bilgiler başlığı altında dört temel beceriye yönelik ölçme ve değerlendirme uygulamaları verilmiştir. Ölçme ve değerlendime çalışmalarında ünite düzeyinde birden fazla becerinin (okuma, yazma, dinleme becerileri) tek sınavla ölçülmesi ifade edilmiştir.

Programlara bakıldığında 2000 yılında yayımlanan programın 1986 programına göre daha kapsamlı ve sistemli bir şekilde hazırlandığı görülmektedir. Daha önce de ifade edildiği gibi her iki programın hedef kitlesi Türkçeyi öğrenememiş yurt dışında yaşayan Türk çocukları ile Türkçeyi yabana dil olarak öğrenecek yabancı çocuklardır. Bu durum her iki programın zayıf yönü olarak 
değerlendirilebilir. Sadece yabancıları hedef alan bir program oluşturulmalıydıya da programda hangi amaç ve kazanımların, uygulamaların hangi hedef kitle için olduğu belirtilmeliydi (1986 programının bazı amaçlarında parantez içinde belirtildiği gibi).

Yapılan bu çalışma ile alandaki "yabancı dil olarak Türkçe öğretim programı hiç hazırlanmamıştır", "yabancı dil olarak Türkçe öğretiminde programsızlık sorunu vardır" gibi yanlıs bilgilerin önüne geçileceği düşünülmektedir. Ayrıca programlara ilişkin ortaya konulan verilerin yabanc dil olarak Türkçe öğretiminin neresinde olduğumuz, alanla ilgili dil politikamızın ne olduğu, programların güçlü ve zayıf yönlerinin neler olduğu konusunda araştırmacılara fikir vereceği düşünülmektedir. Böylece yabancı dil olarak Türkçe öğretimi alanında öğretim programı oluşturma tecrübesine sahip olan Millî Eğitim Bakanlığının ve diğer ilgili kurumların daha etkili öğretim programları hazırlamaları için zemin oluşturulacaktır.

Kaynaklar

Açık, F. (2008). Türkiye'de yabancılara türkçeöğretilirken karşılaşılan sorunlar ve çözüm önerileri. I. Uluslararası Türkçe Eğitimi ve Öğretimi Sempozyumu ( 27-28 Mart 2008, Gazi Mağusa, K.K.T.C.) Bildiri Metni. [Online]http://turkoloji.cu.edu.tr/pdf/fatma_acik_yabancilara_turkce_ogretimi.pdf

Altunışık, R., Çoşkun, R., Yıldırım, E., \& Bayraktaroğlu, S. (2010). Sosyal Bilimlerde Araştırma Yöntemleri. Sakarya: Sakarya Kitabevi.

Er, O., Biçer, N. \& Bozkırlı, K.Ç. (2012). Yabancılara Türkçe öğretiminde karşılaşılan sorunların ilgili alan yazını ışığında değerlendirilmesi. Uluslararası Türkçe Edebiyat Kültür Eğitim Dergisi. 1 (2), 51-69.

Erdem, M.D., Gün, M., Şengül, M. \& Özkan, E. (2015). Yabancı dil olarak Türkçe öğretimi ala nında yazılmış bilimsel makalelerdegeçen anahtar sözcüklere ilişkin bir içerik analizi . OMü Eğitim Fakültesi Dergisi, 34(1), 213 237 doi: 10.7822 /omuefd.34.1.13

Göçer, A. ve Moğul, S. (2011). Türkçenin yabancı dil olarak öğretimi ile ilgili çalışmalara genel bir bakış. Turkish Studies - International Periodical For The Languages, terature and History of Turkish or Turkic 6(3), 797810.

Kara, M. (2011). Avrupa dilleri öğretimi ortak çerçeve metni doğrultusunda Türkçe öğrenen yabancılara A1-A2 seviyesinde Türkçe öğretim programı örneği. Zeitschrift für die Welt der Türken/ Journal of World of Turks, 3 (3), 157-195.

Karasar, N. (2008). Bilimsel Araştırma Yöntemi: Kavramlar, IIkeler, Teknikleri. Ankara: Nobel Yayın Dağıtım.

Millî Eğitim Bakanlığı (2000). Yurt Dışındaki Türk Çocukları Iç̧in Türkçe (1-10. Sınıflar), Türk Kültürü (4-10. Sınıflar) ve Yabana Dil Olarak Türkçe (6-11. Sınıflar) Dersleri Öğretim Programları. Ankara.

Millî Eğitim Gençlik ve Spor Bakanlığı (1986). Yurt Dışı İşçi Çocukları Türkçe-Türk Kültürü ile Yabancı Dil Olarak Türkçe Öğretim Programları. Ankara. 